\title{
Communication, Organizational Trust, and Innovative Behavior of Makeup Employees in the 20-30s
}

\author{
Dong-Hee $\mathrm{Jin}^{1}$, Eun-Jun Park ${ }^{2 *}$ \\ ${ }^{1}$ Department of Beauty, Seokyeong University, Seoul, Korea \\ ${ }^{2}$ Department of Hair and Makeup Design, College of Beauty Art, Seokyeong University, Seoul, Korea
}

\author{
*Corresponding author: Eun-Jun Park, \\ Department of Hair and Makeup Design, \\ College of Beauty Art, Seokyeong University, \\ 124 Seogyeong-ro, Seongbuk-gu, Seoul \\ 02713, Korea \\ Tel.: +82 29407853 \\ Email: ayamdream@hanmail.net
}

Received April 2, 2018

Revised May 24, 2018

Accepted May 25, 2018

Published September 30, 2018

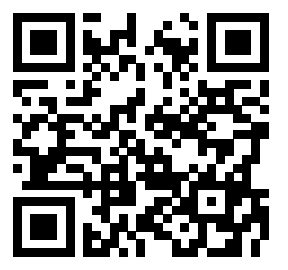

\begin{abstract}
Purpose: The purpose of this study was to examine the communication, organizational trust, and innovative behaviors of 20-30 years old makeup employees and to analyze the inter relationships of the attributes so as to emphasize the importance of smooth communication and trust formation in organizations. Methods: The data collected through the questionnaires of 262 makeup employees in Seoul and Gyeonggi province were analyzed through the Statistical Package for the Social Sciences (SPSS) 22.0. Results: The results revealed that communication has a significant effect on organizational trust and innovation behavior, and in turn, organizational trust has a significant influence on innovative behavior. Thus, communication and organizational trust are extremely important factors for corporate performance. Conclusion: The implications of this study are, as follows. First, a vertical and horizontal communication device mentor-mentee system should be activated. Second, cooperative education and present collaborative tasks should be studied and beneficial goals to solve difficulties should be determined. Third, transparent management policies should be proposed.
\end{abstract}

Keywords: Makeup, Employees, Communication, Organization trust, Innovative behavior

\section{Introduction}

현대사회의 발전과 더불어 서비스 산업의 발전도 급성장을 이 루었으며, 특히 미용 산업은 남녀노소를 막론하고 모두의 관심이 자 더 나은 삶을 위해 꼭 필요한 업종으로 자리잡았다(Yu \& Oh, 2007). 미용 서비스는 다양한 전문 인력의 협동으로 생산되는 특징을 지니고 있어 인적자원이 매우 중요한 비중을 차지하고 있 다. 미용 산업에서 기업의 성패를 좌우하는 것은 서비스를 제공 하는 주체, 즉 종사자라고 할 수 있다(Kook et al., 2016). 종사 자가 곧 기업이라 해도 과언이 아닐 만큼 종사자들이 기업의 이 미지를 대변하는 인적자원인 것이다(Kim \& Bae, 2010). 때문에 기업의 성공을 위해서는 고객 만족도 물론 중요하지만, 그보다 먼저 종사자들의 원활한 커뮤니케이션이 이루어져야 한다(Jang \& Lee, 2014). 이들의 커뮤니케이션을 통한 상호적 관계 형성 과 집단 협업이 기업성과와 직결되기 때문이다. 특히, 신뢰가 기 업의 경쟁력을 높이는 중요한 요소라는 인식이 높아지면서 기업
들은 '질 높은 커뮤니케이션'을 구현하여 구성원 상호간의 이해와 의미 공유를 돕고 신뢰를 촉진할 방법 모색에 힘쓰고 있는 실정 이다(Yoo \& Shin, 2011). 그러나 미용 서비스분야는 타 분야에 비해 단순한 기능인으로만 여겨지는 경우가 많아 조직 내에서의 갈등이 발생하기도 하며, 조직전체의 생산성을 저하시키는 주요 요인이 되기도 한다(Kim, 2007). 이렇듯 종사자들이 서로의 목 적을 이루고 협조적인 관계를 형성하기 위해 커뮤니케이션은 필 수적인 요소이며, 원활한 커뮤니케이션은 조직의 신뢰를 촉진하 게 된다(Kim, 2008).

기업을 성공으로 이끄는 데는 종사자들의 혁신행동 또한 꼭 필 요한 요소이다. 혁신은 새로운 것을 추구하는 의도적 활동이며, 조직성과의 가장 강력한 예측수단이다. 이러한 혁신은 제품, 서 비스 개선, 새로운 시도나 새로운 변화를 추구하는 과정도 포함 된다(Wong et al., 2009).

종사자들의 혁신적 아이디어가 실행에 이르기 위해서는 현장 의 생각과 의견이 경영층에까지 전달 될 수 있는 풍부한 통로 
즉, 커뮤니케이션이 원활해야 하며 종사자들의 생각이나 아이디 어를 편안하게 발언하기 위해서는 무엇보다 조직 내 신뢰가 필요 하다고 한다(Oh \& Choi, 2015).

이렇듯 종사자들의 관계와 역할은 기업의 성패를 결정하는 매 우 중요한 요인이 된다. 관련된 선행연구를 살펴보면, Jang \& Lee (2014)은 조직 커뮤니케이션과 조직몰입의 관계에서 신뢰 의 매개효과에 대해 연구하여 커뮤니케이션과 행동적 몰입에 있 어서 신뢰가 매개효과를 갖는다고 밝혀 신뢰의 중요성에 대해 강 조하였고, Yang et al. (2017)은 상사신뢰와 혁신행동의 관계 연 구에서 신뢰가 혁신행동에 유의한 영향을 미치는 것으로 나타나, 상사 역할의 중요성에 대해 강조하였다. Kang et al. (2016) 또 한 신뢰와 혁신행동의 관계에 대해 연구하여 상사에 대한 신뢰가 높을수록 조직몰입과 혁신행동에 긍정적인 영향을 미친다고 하 였으며, Lee \& Cho (2016)은 조직행동의 결정요인으로서 조직 커뮤니케이션에 대해 연구하여 커뮤니케이션의 중요성을 강조하
였다. 또한 $\operatorname{Lim} \&$ Park (2017)은 조직동일시에 대해 연구하여 조직간의 긍정적 커뮤니케이션과 감정의 중요성에 대해 언급하 기도 하였다.

이렇듯 커뮤니케이션과 신뢰에 대한 연구는 매우 중요한 주제 로 다루어지고 있지만, 커뮤니케이션, 조직신뢰, 혁신행동의 관 계에 관한 연구는 미비한 실정이며, 고부가가치 산업으로 급부상 한 미용서비스 종사자를 대상으로 한 연구 또한 부족한 실정으로 연구의 필요성이 제기된다. 경제성장과 함께 기업화, 조직화 되 어가고 있는 미용서비스업은 타 분야에 비해 종사자의 역할이 중 요하며, 현명한 인적자원의 관리를 위한 연구가 필요하다고 사료 된다.

이에 본 연구는 직장생활을 시작하게 되는 20 대부터 경제활동 이 활발한 시기인 30 대까지의 메이크업 종사자를 대상으로 커뮤 니케이션, 조직신뢰, 혁신행동에 대해 알아보고자 하였으며, 서 로에게 어떤 영향을 미치는지 분석하여 조직 내 원활한 커뮤니케

Table 1. Configuration of a questionnaire

\begin{tabular}{lll}
\hline Research variables & Scale (No. of questions) & Quotation \& applied data \\
General characteristics & Nominal scale (6) & Organization of researchers \\
Communication & 5-point Likert scale (10) & Lee \& Cho (2016), Kim \& Kim (2018) \\
Organization trust & 5-point Likert scale (9) & Jang \& Lee (2014), Song \& Kim (2010) \\
Innovation behavior & 5-point Likert scale (7) & Park et al. (2012), Choi (2017) \\
\hline
\end{tabular}

Table 2. General characteristics

( $\mathrm{N}=\mathbf{2 6 2})$

\begin{tabular}{|c|c|c|c|}
\hline Item & & Frequency $(\mathrm{N})$ & Percentage (\%) \\
\hline \multirow{2}{*}{ Gender } & Man & 56 & 21.4 \\
\hline & Woman & 206 & 78.6 \\
\hline \multirow{2}{*}{ Age } & $20 \mathrm{~s}$ & 154 & 58.8 \\
\hline & $30 s$ & 108 & 41.2 \\
\hline \multirow{3}{*}{ Marital status } & Single & 202 & 77.0 \\
\hline & Married & 57 & 21.8 \\
\hline & Etc. & 3 & 1.2 \\
\hline \multirow{4}{*}{ Rank } & Make-up employees or department store salesman & 135 & 51.5 \\
\hline & Practitioner (artist) & 92 & 35.1 \\
\hline & Manager & 24 & 9.2 \\
\hline & Management (director) & 11 & 4.2 \\
\hline \multirow{5}{*}{ Career } & Less than 1 year & 14 & 5.3 \\
\hline & $1-3$ years & 87 & 33.2 \\
\hline & 3-5 years & 78 & 29.9 \\
\hline & $5-7$ years & 63 & 24.0 \\
\hline & More than 7 years & 20 & 7.6 \\
\hline \multirow{6}{*}{ Monthly average income } & Less than 1 million won & 15 & 5.7 \\
\hline & 1 million won- 2 million won & 116 & 44.3 \\
\hline & 2 million won-3 million won & 73 & 27.9 \\
\hline & 3 million won-4 million won & 32 & 12.2 \\
\hline & 4 million won-5 million won & 20 & 7.6 \\
\hline & More than 5 million won & 6 & 2.3 \\
\hline \multirow{4}{*}{ Number of employees } & Less than 5 & 145 & 55.3 \\
\hline & $5-10$ & 102 & 38.9 \\
\hline & 10 or more & 15 & 5.8 \\
\hline & Sum & 262 & 100.0 \\
\hline
\end{tabular}


이션과 신뢰형성의 중요성을 강조하고 나아가 기업의 성과에 도 움이 되며 인적자원관리에 필요한 정보와 학문적 자료를 제공하 는데 그 목적이 있다.

\section{Methods}

\section{1. 연구대상 및 자료수집}

본 연구의 조사대상은 서울과 경기도 지역의 메이크업 종사자 를 대상으로 설정하였다. 자료의 수집방법으로 자기기입식 설문 지법이 사용되었으며, 예비조사와 본 조사를 통해 연구문제를 해 결하는데 필요한 자료가 수집되었다.

2017년 12월 1일부터 12월 15일까지 총 30부의 예비조사를 통해 측정도구인 설문지의 구성과 내용을 수정 및 보완한 후 본
조사를 실시하였다. 본 조사는 2018년 1월 2일부터 2018년 2 월 28일까지 실시되었고 총 280부의 설문지를 배포하여 수거된 265 부의 설문지 중 분석에 사용되기 불충분하다고 판단되는 3 부 의 설문지를 제외한 262 부가 최종 분석 자료로 사용되었다.

\section{2. 측정항목 및 내용}

본 연구는 자료의 수집을 위해 설문지법이 사용되었다. 설문 문항은 크게 일반적 특성, 커뮤니케이션, 조직신뢰, 혁신행동의 33 문항으로 구성되었으며, 본 연구에 사용된 모든 리커트 척도 는 '1: 전혀 그렇지 않다'에서 '5: 매우 그렇다'까지의 5점 리커트 척도가 사용되었다. 설문지의 구체적인 내용은 Table 1 과 같다.

\section{3. 분석방법}

수집한 자료를 분석하여 연구문제를 검정하기 위해 SPSS

\section{Table 3. Communication}

\begin{tabular}{|c|c|c|c|}
\hline \multirow[b]{2}{*}{ Communication questions } & Variable 1 & Variable 2 & \multirow[b]{2}{*}{ Commonality } \\
\hline & $\begin{array}{c}\text { Vertical } \\
\text { communication }\end{array}$ & $\begin{array}{l}\text { Horizontal } \\
\text { communication }\end{array}$ & \\
\hline I can communicate easily with my boss & 0.827 & 0.235 & 0.739 \\
\hline My supervisor listens to my opinions and influences my business decisions & 0.811 & 0.361 & 0.787 \\
\hline My supervisor's attitude toward communication is sound and moral & 0.718 & 0.389 & 0.667 \\
\hline My boss is good at giving guidance or feedback to solve job related problems & 0.717 & 0.396 & 0.671 \\
\hline I do it concisely and accurately when writing my report to my boss & 0.704 & 0.369 & 0.631 \\
\hline My boss explains successful and unsuccessful performance & 0.656 & 0.386 & 0.578 \\
\hline Colleagues share job related information & 0.333 & 0.856 & 0.843 \\
\hline Communication between peers about job problems and processes is smooth & 0.337 & 0.838 & 0.816 \\
\hline $\begin{array}{l}\text { Communication between peers contributes to and motivates the organization to achieve } \\
\text { its goals }\end{array}$ & 0.398 & 0.783 & 0.776 \\
\hline My colleagues have sufficient ability to communicate & 0.388 & 0.755 & 0.732 \\
\hline Eigen value & 3.846 & 3.395 & \\
\hline Description variant (\%) & 38.461 & 33.947 & \\
\hline Cumulative variance (\%) & 38.461 & 72.408 & \\
\hline Cronbach's $\alpha$ & 0.903 & 0.913 & \\
\hline
\end{tabular}

Bartlett's unit matrix=1892.964 (df=45; Sig.=0.000); KMO=0.932; df, degree of freedom; Sig, significance; KMO, Kaise-Mayer-Olkin.

\section{Table 4. Organizational trust}

\begin{tabular}{|c|c|c|c|}
\hline \multirow[b]{2}{*}{ Organizational trust questions } & Variable 1 & Variable 2 & \multirow[b]{2}{*}{ Commonality } \\
\hline & $\begin{array}{c}\text { Company } \\
\text { trust }\end{array}$ & $\begin{array}{l}\text { Relationship } \\
\text { trust }\end{array}$ & \\
\hline We are fully aware of our goals and mission & 0.845 & 0.199 & 0.775 \\
\hline The evaluation criteria for our employees are fair & 0.832 & 0.308 & 0.787 \\
\hline Our company can give opinions at any time about management policies and systems & 0.807 & 0.282 & 0.731 \\
\hline Our company thinks that the procedures for determining salary and bonus increases are fair & 0.758 & 0.364 & 0.707 \\
\hline Our company has enough abilities to carry out its duties & 0.751 & 0.333 & 0.675 \\
\hline The members of my organization have great faith in each other & 0.325 & 0.853 & 0.834 \\
\hline The members of my organization are trying to maintain an interdependent relationship & 0.294 & 0.819 & 0.757 \\
\hline The members of my organization understand and acknowledge me & 0.259 & 0.817 & 0.734 \\
\hline The members of my organization are honest with each other & 0.289 & 0.774 & 0.683 \\
\hline Eigen value & 3.540 & 3.123 & \\
\hline Description variant (\%) & 39.331 & 34.704 & \\
\hline Cumulative variance (\%) & 39.331 & 74.035 & \\
\hline Cronbach's $\alpha$ & 0.903 & 0.889 & \\
\hline
\end{tabular}

Bartlett's unit matrix=1581.881 (df=36; Sig.=0.000), KMO=0.906; df, degree of freedom; Sig, significance; KMO, Kaise-Mayer-Olkin. 
22.0 (IBM, USA)이 사용되었고, 자료의 분석방법은 연구문제에 맞게 순차적으로 적용되었으며 다음과 같다.

첫째, 조사대상의 일반적 특성을 알아보기 위해 빈도분석을 하 였다. 둘째, 커뮤니케이션, 조직신뢰, 혁신행동의 차원을 알아보 기 위해 요인분석과 신뢰도분석을 하였다. 요인의 추출방법으로 주성분분석법이 사용되었고, 요인의 회전방법으로는 Varimax가 사용되었다. 셋째, 커뮤니케이션이 조직신뢰, 혁신행동에 미치는 영향을 알아보기 위해 회귀분석을 하였다. 넷째, 조직신뢰가 혁 신행동에 미치는 영향을 알아보기 위해 회귀분석을 하였다. 회귀 분석에서 독립변수의 투입방법으로는 입력 방법이 사용되었다.

\section{Results and Discussion}

\section{1. 조사대상의 일반적 특성}

조사대상인 메이크업 종사자의 일반적 특성을 알아보기 위해 빈도분석을 실시한 결과는 다음 Table 2 와 같다.

성별은 남성 $21.4 \%$, 여성 $78.6 \%$ 로 여성이 높게 나타났고, 연 령은 20 대 $58.8 \%, 30$ 대 $41.2 \%$ 로 20 대가 높았다. 결혼여부는 미혼 $77.0 \%$, 기혼 $21.8 \%$, 기타 $1.2 \%$ 로 미혼이 가장 높게 나 타났고, 직급의 경우 메이크업 회사/백화점 판매원 $51.5 \%$, 실
무자(아티스트) $35.1 \%$, 관리자(매니저, 실장) $9.2 \%$, 경영자(원 장, 점장) $4.2 \%$ 로 메이크업 회사/백화점 판매원이 가장 높게 나 타났다. 경력을 알아본 결과, 1 년 미만 $5.3 \%, 1$ 년에서 3 년 미 만 $33.2 \%, 3$ 년에서 5년 미만 $29.9 \%, 5$ 년에서 7 년 미만 $24.0 \%$, 7년 이상 $7.6 \%$ 로 1 년에서 3 년 미만이 가장 높게 나타났고, 월 평균 소득은 100 만원 미만 $5.7 \%, 100$ 만원에서 200 만원 미만 $44.3 \%, 200$ 만원에서 300 만원 미만 $27.9 \%, 300$ 만원에서 400만 원 미만 $12.2 \%, 400$ 만원에서 500 만원 미만 $7.6 \%, 500$ 만원 이 상 $2.3 \%$ 로 100 만원에서 200 만원 미만이 가장 높게 나타났다. 직원 수를 알아본 결과, 5 명 미만 $55.3 \%, 5$ 명에서 10 명 미만 $38.9 \%, 10$ 명 이상 $5.8 \%$ 로 5 명 미만이 가장 높게 나타났다.

\section{2. 커뮤니케이션, 조직신뢰, 혁신행동의 신뢰도 및 타당도}

커뮤니케이션, 조직신뢰, 혁신행동 문항에 대한 타당성 및 신 뢰도 검증을 위해 요인분석과 신뢰도 분석을 실시하였다.

커뮤니케이션은 Table 3 과 같이 수직적 커뮤니케이션, 수평 적 커뮤니케이션의 두 가지 요인이 도출되었다. Bartlett의 단 위행렬 점검 결과 $\chi^{2}=1892.964(\mathrm{df}=45$, Sig. $=0.000), \mathrm{KMO}$ 값 0.932 로 나타났으며, 공통성은 0.578 이상, 전체 설명력은 $72.4 \%$, 신뢰도계수는 0.903 이상으로 나타났다. 조직신뢰는 Table 4 와 같이 회사신뢰, 관계신뢰의 두 가지 요인이 도출되

\section{Table 5. Innovative behavior}

\begin{tabular}{lcc}
\hline Innovative behavior questions & Variable & Commonality \\
I want to find new technologies or techniques & 0.849 & 0.721 \\
I develop creative ideas & 0.842 & 0.709 \\
I promote ideas to others and discuss them with others & 0.836 & 0.698 \\
I apply appropriate planning to the workplace in order to implement new ideas & 0.836 \\
I try to gather some support from the people around me about my innovative ideas & 0.823 \\
I want to be supported by my colleagues for my innovative ideas & 0.818 \\
I scrutinize the practical value of my innovative ideas & 0.808 \\
Eigen value & 4.826 \\
Description variant (\%) & 68.940 \\
Cumulative variance (\%) & 68.940 \\
Cronbach's $\alpha$ & 0.924 \\
\hline
\end{tabular}

Bartlett's unit matrix=1220.169 (df=21; Sig.=0.000), KMO=0.919; df, degree of freedom; Sig, significance; KMO, Kaise-Mayer-Olkin.

Table 6. The impact of communication on organizational trust

\begin{tabular}{|c|c|c|c|c|c|c|c|}
\hline Dependent variables & Independent variables & $\mathrm{B}$ & SE B & $\beta$ & $t$ & & $p$ \\
\hline \multirow{3}{*}{ Company trust } & (a constant) & 0.000 & 0.052 & & 0.000 & & 1.000 \\
\hline & Vertical communication & 0.393 & 0.052 & 0.393 & 7.547 & *** & 0.000 \\
\hline & Horizontal communication & 0.381 & 0.052 & 0.381 & 7.315 & **** & 0.000 \\
\hline \multicolumn{8}{|c|}{ adj $\mathrm{R}^{2}=0.294, F=55.229, p=0.000$} \\
\hline \multirow{3}{*}{ Relationship trust } & (a constant) & 0.000 & 0.051 & & 0.000 & & 1.000 \\
\hline & Vertical communication & 0.389 & 0.051 & 0.389 & 7.686 & *** & 0.000 \\
\hline & Horizontal communication & 0.430 & 0.051 & 0.430 & 8.493 & *** & 0.000 \\
\hline \multicolumn{8}{|c|}{ Modified $\mathrm{R}^{2}=0.331, F=65.602, p=0.000$} \\
\hline
\end{tabular}

${ }^{* * *} p<0.001 ; \mathrm{B}$, unstandardized coefficient; SE B, standard error B; $\beta$, standardized coefficient; $t, t$-value; $p$, probability of significance; adj $\mathrm{R}^{2}$, adjusted correlation coefficient; Modified $\mathrm{R}^{2}$, modified correlation coefficient; $F, F$-value. 
었다. Bartlett의 단위행렬 점검 결과 $\chi^{2}=1581.881(\mathrm{df}=36$, Sig. =0.000), $\mathrm{KMO}$ 값 0.906으로 나타났으며, 공통성은 0.675 이상, 전체 설명력은 $74.0 \%$, 신뢰도계수는 0.889 이상으로 나 타났다. 혁신행동은 Table 5 와 같이 하나의 요인이 도출되었 으며, Bartlett의 단위행렬 점검 결과 $\chi^{2}=1220.169(\mathrm{df}=21$, Sig. $=0.000), \mathrm{KMO}$ 값 0.919로 나타났으며, 공통성은 0.653이 상, 설명력은 $68.9 \%$, 신뢰도 계수는 0.924 로 나타났다.

\section{3. 커뮤니케이션이 조직신뢰에 미치는 영향}

커뮤니케이션이 조직신뢰의 하위요인인 회사신뢰와 관계신로 에 미치는 영향에 대한 회귀분석 결과는 Table 6 과 같다. 회사신 뢰에 수직적 커뮤니케이션과 수평적 커뮤니케이션이 유의미하게 영향을 미치는 것으로 나타났고, 수직적 커뮤니케이션과 수평적 커뮤니케이션이 회사신뢰 요인을 예측하는데 $29.4 \%$ 의 설명력을 갖는 것으로 나타났다. 독립변수의 영향력을 살펴보면 수직적 커 뮤니케이션과 수평적 커뮤니케이션이 유의미하게 $(p<0.001)$ 정 $(+)$ 적을 영향을 미치는 것으로 나타났다. 이는 수직적 커뮤니 케이션과 수평적 커뮤니케이션이 높아질수록 회사신뢰도 높아 지고 있음을 의미한다. 변수의 영향력은 수직적 커뮤니케이션 $\beta=0.393$, 수평적 커뮤니케이션 $\beta=0.381$ 순으로 나타났다.

관계신뢰에 수직적 커뮤니케이션과 수평적 커뮤니케이션이 유 의미하게 영향을 미치는 것으로 나타났고, 수직적 커뮤니케이션 과 수평적 커뮤니케이션이 관계신뢰 요인을 예측하는데 $33.1 \%$ 의 설명력을 갖는 것으로 나타났다. 독립변수의 영향력을 살펴 보면 수직적 커뮤니케이션과 수평적 커뮤니케이션이 유의미하게 $(p<0.001)$ 정 $(+)$ 적을 영향을 미치는 것으로 나타났다. 이는 수 직적 커뮤니케이션과 수평적 커뮤니케이션이 높아질수록 관계신 뢰도 높아지고 있음을 의미한다. 변수의 영향력은 수평적 커뮤니 케이션 $\beta=0.430$, 수직적 커뮤니케이션 $\beta=0.389$ 순으로 나타났
다. 이는 수직적 커뮤니케이션은 회사에 대한 신뢰형성에 더 도 움을 주고 수평적 커뮤니케이션은 관계에 대한 신뢰형성에 더 영 향을 주는 것으로 판단할 수 있다. Yoo \& Shin (2011)의 연구에 서 상하간 개방적 커뮤니케이션이 신뢰에 유의한 영향을 미치는 것으로 나타났으며, 커뮤니케이션에 만족할수록 신뢰가 높아진 다고 하였다. Lee (2017)의 연구에서도 커뮤니케이션이 조직신 뢰에 유의한 영향을 미치는 것으로 나타나 본 논문과 유사한 결 과를 보였으며, 매우 중요한 요인임을 강조하고 있다.

\section{4. 커뮤니케이션이 혁신행동에 미치는 영향}

커뮤니케이션이 혁신행동에 미치는 영향에 대한 회귀분석 결 과는 Table 7과 같다. 혁신행동에 수직적 커뮤니케이션과 수평 적 커뮤니케이션이 유의미하게 영향을 미치는 것으로 나타났고, 수직적 커뮤니케이션과 수평적 커뮤니케이션이 혁신행동 요인 을 예측하는데 $52.5 \%$ 의 설명력을 갖는 것으로 나타났다. 독립 변수의 영향력을 살펴보면 수직적 커뮤니케이션과 수평적 커뮤 니케이션이 유의미하게 $(p<0.001)$ 정 $(+)$ 적의 영향을 미치는 것 으로 나타났다. 이는 수직적 커뮤니케이션과 수평적 커뮤니케이 션이 높아질수록 혁신행동도 높아지고 있음을 의미한다. 변수의 영향력은 수평적 커뮤니케이션 $\beta=0.532$, 수직적 커뮤니케이션 $\beta=0.496$ 순으로 나타났다. 이는 수평적 커뮤니케이션이 기업의 혁신과 발전에 더 긍정적인 효과를 가져온다는 것을 보여주고 있 다. Shon \& Lee (2016)의 커뮤니케이션과 신뢰에 대한 연구에 서 일반적 커뮤니케이션은 신뢰에 유의한 영향을 미치지 않고, 심리적 커뮤니케이션이 신뢰에 유의한 영향을 미친다고 나타나 커뮤니케이션 자체보다 감정의 교류를 할 수 있는 커뮤니케이션 의 중요성을 강조하고 있다. 즉 신뢰형성에 영향을 미치는 커뮤 니케이션은 수직적인 업무회의가 아닌 원활한 소통할 수 있는 대 화라고 판단된다.

Table 7. The influence of communication on innovative behavior

\begin{tabular}{|c|c|c|c|c|c|c|c|}
\hline Dependent variables & Independent variables & B & SE B & $\beta$ & $t$ & & $p$ \\
\hline \multirow{3}{*}{ Innovative behavior } & (a constant) & 3.569 & 0.033 & & 109.650 & & 0.000 \\
\hline & Vertical communication & 0.379 & 0.033 & 0.496 & 11.620 & $* * *$ & 0.000 \\
\hline & Horizontal communication & 0.406 & 0.033 & 0.532 & 12.459 & *** & 0.000 \\
\hline \multicolumn{8}{|c|}{ Modified $\mathrm{R}^{2}=0.525, F=145.117, p=0.000$} \\
\hline
\end{tabular}

${ }_{* * *} p<0.001 ; \mathrm{B}$, unstandardized coefficient; SE B, standard error B; $\beta$, standardized coefficient; $t, t$-value; $p$, probability of significance; Modified $\mathrm{R}^{2}$, modified correlation coefficient; $F, F$-value.

Table 8. The effect of organizational trust on innovative behavior

\begin{tabular}{|c|c|c|c|c|c|c|c|}
\hline Dependent variables & Independent variables & B & SE B & $\beta$ & $t$ & & $p$ \\
\hline \multirow{3}{*}{ Innovative behavior } & (a constant) & 3.569 & 0.029 & & 122.088 & & 0.000 \\
\hline & Company trust & 0.425 & 0.029 & 0.556 & 14.506 & *** & 0.000 \\
\hline & Relationship trust & 0.426 & 0.029 & 0.557 & 14.542 & $* * *$ & 0.000 \\
\hline
\end{tabular}

Modified $\mathrm{R}^{2}=0.617, F=210.950, p=0.000$

${ }^{* * *} p<0.001$; B, unstandardized coefficient; SE B, standard error B; $\beta$, standardized coefficient; $t, t$-value; $p$, probability of significance; Modified $\mathrm{R}^{2}$, modified correlation coefficient; $F, F$-value. 


\section{5. 조직신뢰가 혁신행동에 미치는 영향}

조직신뢰가 혁신행동에 미치는 영향에 대한 회귀분석 결과는 Table 8과 같다. 혁신행동에 회사신뢰와 관계신뢰가 유의미하게 영향을 미치는 것으로 나타났고, 회사신뢰와 관계신뢰가 혁신행 동 요인을 예측하는데 $61.7 \%$ 의 설명력을 갖는 것으로 나타났다. 독립변수의 영향력을 살펴보면 회사신뢰와 관계신뢰가 유의미하 게 $(p<0.001)$ 정 $(+)$ 적의 영향을 미치는 것으로 나타났다. 회사신 뢰와 관계신뢰가 높아질수록 혁신행동도 높아지고 있음을 의미 한다. 변수의 영향력은 관계신뢰 $\beta=0.557$, 회사신뢰 $\beta=0.556$ 순으로 나타났다. Yang et al. (2017)의 연구에서 상사에 대한 신뢰가 구성원들의 혁신행동에 직접적인 원인으로 작용할 때, 동 료들간의 신뢰는 이를 지속시키고 지지해 준다고 나타났으며, Kang et al. (2016)의 연구에서도 조직 및 상사에 대한 신뢰가 높을수록 조직몰입과 혁신행동에 긍정적 영향을 미치는 것으로 나타나 본 연구의 결과와 유사하였다. Oh \& Choi (2015)의 연 구에서는 신뢰가 혁신에 긍정적 영향을 미치며, 계획적 변화를 시도할 때 더욱 극대화된다고 강조하였다.

\section{Conclusion}

본 연구는 20-30대 메이크업 종사자의 커뮤니케이션, 조직신 뢰, 혁신행동에 대해 알아보고자 하였으며, 서로에게 어떤 영향 을 미치는지 분석하여 조직 내 원활한 커뮤니케이션과 신뢰형성 의 중요성을 강조하고 나아가 기업의 성과에 도움을 주며 인적자 원관리에 필요한 정보와 학문적 자료를 제공하는 것을 목적으로 하였다. 서울, 경기 지역의 메이크업 종사자를 대상으로 설문지 법을 통해 수집된 자료 262부는 SPSS 22.0 을 통해 분석되었고 적용된 분석방법은 빈도분석, 요인분석, 신뢰도분석, 회귀분석이 었다.

연구결과는 다음과 같았다. 첫째, 조사대상의 일반적 특성을 알아보기 위해 빈도분석을 실시한 결과 성별은 여성이 높았고, 연령은 20 대가, 결혼여부는 미혼이, 직급은 메이크업 회사/백화 점 판매원이 가장 높게 나타났다. 경력은 1 년에서 3 년 미만이, 월 평균 소득은 100 만원에서 200 만원 미만이, 직원 수는 5 명 미 만이 가장 높게 나타났다. 둘째, 커뮤니케이션, 조직신뢰, 혁신 행동을 요인분석 한 결과, 커뮤니케이션은 수직적 커뮤니케이션, 수평적 커뮤니케이션의 두 가지 요인이 도출되었고, 조직신뢰는 회사신뢰, 관계신뢰의 두 가지 요인이 도출되었으며, 혁신행동은 단일차원으로 묶여 하나의 요인이 도출되었다. 셋째, 커뮤니케이 션이 조직신뢰에 미치는 영향을 알아본 결과, 유의한 영향을 미 치는 것으로 나타났다. 넷째, 커뮤니케이션이 혁신행동에 미치는 영향을 알아본 결과, 유의한 영향을 미치는 것으로 나타났다. 다 섯째, 조직신뢰가 혁신행동에 미치는 영향을 알아본 결과, 유의
한 영향을 미치는 것으로 나타났다.

이렇듯 커뮤니케이션, 조직신뢰, 혁신행동이 유의한 영향관계 임을 확인하였으며, 연구 결과에 따른 시사점으로는 첫째, 수직 적 커뮤니케이션과 수평적 커뮤니케이션 모두 조직신뢰에 유의 한 영향을 미치는 것으로 나타나 상사와의 커뮤니케이션과 동료 와의 커뮤니케이션 모두 중요한 요인임이 확인되었다. 지금까지 미용서비스업은 종사자와 고객과의 관계에 초점을 맞추는 외부 적 커뮤니케이션을 중요시해왔으나 이제는 내부적 커뮤니케이션 을 활성화시키는 장치를 마련해야 한다. 보여주기 식의 업무회의 가 아닌 상사는 물론 동료와의 멘토-멘티제를 활성화하여 조직 내 수직적, 수평적으로 원활한 커뮤니케이션이 이루어질 수 있도 록 해야 할 것이다. 둘째, 커뮤니케이션이 혁신행동에 유의한 영 향을 미치는 것을 확인하였고 수직적 커뮤니케이션보다 수평적 커뮤니케이션이 혁신행동에 더 큰 영향을 미치는 것을 알 수 있 었다. 이는 동료와의 관계가 협력적일 때 혁신행동이 수월하게 발휘된다고 보여지므로 종사자들끼리 협동심을 기를 수 있도록 지원해 주어야 한다. 기업이나 경영자가 종사자들에게 협동교육 을 지원해주거나, 협동과제를 제시하여 함께 공부하고 어려움을 풀어나갈 수 있는 유익한 목표를 만들어 주어야 한다. 셋째, 조 직신뢰가 혁신행동에 유의한 영향을 미치는 것으로 나타났다. 기 업의 성과를 위해서는 신뢰가 중요한 요인임을 확인할 수 있었으 며 신뢰형성을 위해서는 우선적으로 투명성이 보장되어야 한다. 기업은 승진, 임금제도에 대해 투명하게 공개해야 하며, 종사자 들의 능력에 맞는 직급과 보상이 따라야 할 것이다. 대부분 경영 자들에 의해 결정되지만 종사자들의 의견이 반영될 수 있는 제도 를 마련한다면 신뢰와 혁신행동에 긍정적인 효과를 가져올 수 있 을 것이다.

최근 조직에 있어 커뮤니케이션과 신뢰는 중요하게 인식되고 있다. 특히 신뢰는 타인의 미래 행동이 자신에게 호의적이거나, 최소한 악의적이지 않을 가능성에 대한 기대와 믿음을 말하는 것 으로, 본 연구에서 커뮤니케이션, 조직신뢰, 혁신행동의 관계에 대해 연구하여, 기업성과의 원동력이 되는 혁신행동에 대한 기여 여부를 밝히는 연구가 될 것으로 사료된다. 나아가 미용 산업의 발전을 위하여 실질적으로 적용 될 수 있기를 바란다.

본 연구는 일부 지역의 메이크업종사자를 대상으로 표본구성 을 했으므로 연구 결과를 일반화 시키는데 제한 점을 가질 수 있 다. 또한 다양한 변수를 기준으로 세분화하여 후속연구가 이루어 지길 기대한다.

\section{References}

Choi HJ. The effect of perception level for ambidexterity innovation on organizational commitment and innovation 
behavior: focusing moderating role of environmental dynamism. Tourism Research, 42: 173-195, 2017.

Jang SY, Lee HJ. The effect of organizational communication on organizational commitment in a hotel: the mediating role of trust. Korean Journal of Hospitality and Tourism, 23: 145-164, 2014.

Kang KM, Ha YJ, Kim YK. The moderating effect of shared value in the relationship between trust, commitment of an organization, innovative action. Health Service Management Review, 10: 27-38, 2016.

Kim MJ, Bae YJ. A study on the impact of nonverbal communication on customer satisfaction and word of mouth effect in the beauty service. Asian Journal of Beauty and Cosmetology, 8: 1-13, 2010.

Kim JH. The balanced scorecard (BSC) communication and firm performance: the role of absorptive capacity, trust, and learning. Korean Accounting Journal, 17: 287-321, 2008.

Kim YS, Kim G. Effect of hotel middle manager's communication on the organizational commitment and organizational culture: moderating effect of organizational commitment. The Journal of the Korea contents Association, 18: 412421, 2018.

Kim YS. A study on the satisfaction at estheticians' job performance. Journal of The Korean Society of Cosmetology, 13: 53-66, 2007.

Kook HR, Na HY, Kim SH. The effects of nonverbal communication on customer trust and customer loyalty in hair and beauty service providers. Journal of The Korean Society of Cosmetology, 22: 1016-1025, 2016.

Lee G. Communication, organizational trust, and organizational involvement. Locality \& Communication, 21: 65-87, 2017.

Lee JG, Cho YJ. The effect of organizational communication on organizational citizenship behavior (OCB) within fire stations: focusing on mediating effects of trust and organizational commitment. Korean Public
Administration Review, 50: 243-272, 2016.

Lim YK, Park E. Effects of organizational identification on organizational phase and relative deprivation of beauticians. Asian Journal of Beauty and Cosmetology, 15: 204-213, 2017.

Oh JY, Choi BW. The influence of trust on innovation: mediated moderating effect of planned change through organizational communication. Productivity Review, 29: 35-60, 2015.

Park KK, Shin YH, Choi HS. Antecedents and outcomes of innovative behavior. Koreanische Zeitschriftfuer Wirtschaftswissenschaften, 30: 95-119, 2012.

Shon JK, Lee JE. A study on the effects of psychological communication, self-efficacy, trust toward the organizational loyalty in hotel employee. International Journal of Tourism Management and Sciences, 31: 305-323, 2016.

Song U, Kim YB. The relationship between organizational trust and innovational behavior: focusing on the mediation impacts of the organizational commitment. Journal of Social Science, 26: 127-151, 2010.

Wong A, Tjosvold D, Liu C. Innovation by teams in Shanghai, China: cooperative goals for group confidence and persistence. British Journal of Management, 20: 238251, 2009.

Yang SG, Kim SY, Ahn SI. The effect of innovative behavior on superior trust: focused on moderating effect of job characteristics. The Korean Leadership Quarterly, 8: 131-163, 2017.

Yu MJ, Oh PJ. A study on the effects of service quality of beauty health on customer satisfaction. Korean Business Education Review, 46: 107-122, 2007.

Yoo SW, Shin HC. A study of internal communication climate factors and their effects on trust among employees. Korean Journal of Journalism \& Communication Studies, 55: 54-81, 2011. 


\section{국문초록}

\section{0-30대 메이크업 종사자의 커뮤니케이션, 조직신뢰, 혁신행동에 관한 연구}

진동희 ${ }^{1}$ 박은준 ${ }^{2 *}$

${ }^{1}$ 서경대학교 미용예술학과, 서울, 한국

${ }^{2}$ 서경대학교 미용예술대학 헤어메이크업디자인학과, 서울, 한국

목적: 본 연구는 20-30대 메이크업 종사자의 커뮤니케이션, 조직신뢰, 혁신행동에 대해 알아보고자 하였으며, 서로에게 어떤 영향 을 미치는지 분석하여 조직 내 원활한 커뮤니케이션과 신뢰형성의 중요성을 강조하는 것을 목적으로 하였다. 방법: 서울, 경기 지 역의 메이크업 종사자를 대상으로 설문지법을 통해 수집된 자료 262부는 Statistical Package for the Social Sciences (SPSS)을 통해 분석되었다. 결과: 연구결과 커뮤니케이션이 조직신뢰, 혁신행동에 유의한 영향을 미치는 것으로 나타났으며, 조직신뢰 또한 혁신 행동에 유의한 영향을 미치는 것으로 나타났다. 이렇듯 커뮤니케이션과 조직신뢰가 기업의 성과에 매우 중요한 요인임을 확인하였 다. 결론: 본 연구 결과에 따른 시사점으로는 첫째, 수직적, 수평적 커뮤니케이션 장치인 멘토-멘티제의 활성화, 둘째, 협동교육 지 원, 협동과제 제시 등, 함께 공부하고 어려움을 풀어나갈 수 있는 유익한 목표의 설정, 셋째, 투명성 있는 경영정책을 제안한다.

핵심어: 메이크업, 종사자, 커뮤니케이션, 조직신뢰, 혁신행동

\section{참고문헌}

강광민, 하윤주, 김윤경. 대학병원 간호사의 신뢰 및 조직몰입과 혁신행동과의 관계에서 공유가치의 조절효과. 의료경영학 연구, 10: 27-38, 2016.

국혜란, 나해윤, 김서희. 헤어미용서비스 제공자의 비언어적 커뮤니케이션이 고객신뢰와 고객충성도에 미치는 영향. 한국 미용학회지, 22: 1016-1025, 2016.

김미정, 배윤지. 미용서비스 제공자의 비언어적 커뮤니케이션이 고객만족과 구전효과에 미치는 영향. 아시안뷰티화장품학 술지, 8: 1-13, 2010.

김연선, 김건. 호텔 중간관리자의 커뮤니케이션이 조직몰입과 조직문화에 미치는 영향. 한국콘텐츠학회논문지, $13: 412-$ $421,2013$.

김연숙. 피부미용 종사자들의 직업만족에 관한 연구. 한국미용학회지, 12: 53-66, 2007.

김진환. BSC의 커뮤니케이션과 기업성과: 흡수능력, 신뢰 및 학습의 역할. 회계저널, 17: 287-321, 2003.

박경규, 신이현, 최항석. 혁신행동의 선행요인과 결과요인에 관한 연구. 경상논총, 30: 95-119, 2012.

손재근, 이정은. 심리적 커뮤니케이션, 자기효능감, 신뢰, 충성도간의 인과관계. 관광연구, 31: 305-323, 2016.

송운석, 김용빈. 조직신뢰와 혁신행동과의 관계에 관한 연구: 조직몰입의 매개효과를 중심으로. 사회과학연구, $26: 127-$ 151,2010

양석곤, 김성용, 안성익. 상사신뢰가 혁신행동에 미치는 영향: 직무특성의 조절효과를 중심으로. 리더십연구, 8: 131163, 2017.

오주연, 최병우. 신뢰가 혁신에 미치는 영향: 조직커뮤니케이션을 통한 계획적변화의 매개된 조절효과. 생산성논집, $29:$

35-60, 2015.

유명자, 오평자. 미용보건 서비스품질이 고객만족에 미치는 영향에 관한 연구. 경영교육연구, 46: 107-122, 2007.

유선욱, 신호창. 사내 커뮤니케이션 기풍적 요인과 조직 구성원간 신뢰와의 관계에 대한 연구. 한국언론학보, $55: 54-81$, 2011.

이건혁. 커뮤니케이션과 조직 신뢰, 그리고 조직 몰입: 지식창출의 효과를 중심으로. 지역과 커뮤니케이션, 21: $65-87$, 
2017.

이중길, 조윤직. 소방조직 내 조직시민행동의 결정요인으로서 조직커뮤니케이션의 영향: 신뢰와 조직몰입의 매개효과를 중심으로. 한국행정학보, 50: 243-272, 2016.

임윤경, 박은준. 미용종사자의 조직 동일시가 조직위상과 상대적 박탈감에 미치는 영향. 아시안뷰티화장품학술지, $15:$ 204-213, 2017.

장세유, 이희정. 호텔 조직 커뮤니케이션이 조직 몰입에 미치는 영향: 신뢰의 매개효과를 중심으로. 호텔경영학연구, 23 : 145-164, 2014.

최호준. 양면성 혁신의 인식수준이 조직몰입 및 혁신행동에 미치는 영향: 환경 동태성의 조절효과를 중심으로. Tourism Research, 42: 173-195, 2017. 


\title{
中文摘要
}

\section{0-30岁化妆师的沟通, 组织信任, 创新行为}

\author{
陣東姫 ${ }^{1}$, 朴銀俊 $2^{*}$ \\ ${ }^{1}$ 西京大学美容艺术学科, 首尔, 韩国 \\ 西京大学美容艺术大学美发化妆设计系, 首尔, 韩国
}

目的: 探讨 20-30岁化妆师的沟通, 组织信任和创新行为, 并分析这些属性之间的相互关系, 强调在组织中顺畅 沟通和信任形成的重要性为目的。方法: 对首尔和京畿道地区的化妆师为对象进行问卷调查, 将收集的262份资 料利用Statistical Package for the Social Sciences (SPSS) 进行分析。结果: 结果表明, 沟通对组织信任和 创新行为有显著影响, 反过来, 组织信任对创新行为也有显着影响。因此, 沟通和组织信任是企业绩效的极其 重要的因素。结论: 这项研究的意义如下: 首先, 应激活垂直和水平沟通导师-被辅导者系统; 其次, 提供合作 教育和合作任务，并设立有萾的目标来解决困难；第三，提出透明的管理政策。

关键词: 化妆, 从业者, 沟通, 组织信任, 创新行为 